\title{
40. SOURCES, PRESERVATION, MATURATION, AND MIGRATION OF ORGANIC MATTER IN NEOGENE SEDIMENTS FROM THE CONTINENTAL MARGIN OFF CALIFORNIA AND BAJA CALIFORNIA: A SYNTHESIS OF ORGANIC GEOCHEMICAL STUDIES FROM DEEP SEA DRILLING PROJECT LEG 631
}

\author{
Bernd R. T. Simoneit, Institute of Geophysics and Planetary Physics, University of California, \\ Los Angeles, California \\ Philip A. Meyers, Oceanography Program, Department of Atmospheric and Oceanic Science, \\ The University of Michigan, Ann Arbor, Michigan \\ and \\ Colin P. Summerhayes, Exxon Production Research Company, P. O. Box 2189, Houston, Texas
}

\begin{abstract}
This synthesis of organic geochemical studies from Leg 63 was designed to answer fundamental questions about the source, deposition, preservation, and alteration of organic matter off California and Baja California. The answers to these questions help to determine the extent and degree of influence of paleoenvironmental factors, the understanding of which was among the main objectives of drilling on this leg.

The organic matter is mostly marine, and was deposited as pelagic sediment. Terrigenous components are abundant in the deep sea fan at Site 471 , and in the upper Pliocene and Quaternary rocks and sediments of the California Borderland. Total organic matter (TOC) is highest in the upper Miocene to lower Pliocene rocks and sediments at Site 467 , and in the middle Miocene rocks and sediments at Site 468 , probably as a response to increased upwelling and high productivity, accompanied by depletion of oxygen in the oxygen minimum zone. Deeper water sites contain little organic matter, and do not exhibit a record of changes in surface circulation. All of the drilled sections are thermally immature, but light hydrocarbons are being generated in small amounts deep at Site 467. Light hydrocarbons that were probably generated in the vicinity of a sill at the bottom of Hole 471 have migrated in substantial amounts into the overlying section.
\end{abstract}

\section{INTRODUCTION}

The study of organic matter in deep sea sediments can be of major importance in elucidating regional geological problems. The organic matter deposited as sediment contains a record of sedimentary processes, and reflects as well the productivity of surface waters, the degree of oxygenation of bottom waters, and the magnitude of subsurface diagenesis. Furthermore, organic matter is more sensitive than are other geological thermometers to thermal effects in the subsurface. Our approach to Leg 63 is to use organic geochemistry to examine several major problems of geological importance:

1) What is the source of the organic matter-marine or terrestrial?

2) How was it deposited-by pelagic sedimentation or turbidity currents?

3) How was it preserved-in oxic or anoxic environments?

4) What paleoenvironmental conditions or changes can be detected from the interaction of source, deposition, and preservation of organic matter?

5) What has been the effect of thermal stress from either regional heat flow or volcanic intrusion?

\footnotetext{
${ }^{1}$ Initial Reports of the Deep Sea Drilling Project, Volume 63.
}

6) What are the products of this catagenesis, and to what extent have they migrated through the section?

We have addressed these questions by reviewing the organic geochemical reports published in this volume, and by synthesizing the data and interpretations given in those reports.

The main objective of Leg 63 was to examine the history of Neogene circulation along the Californian margin of the northeast Pacific Ocean. The organic geochemical studies contribute to an understanding of circulation history only at Sites 467 and 468 . These sites lie in shallow water beneath upwelling centers where productivity was high and oxygen low, conditions favoring the accumulation of organic matter. The other sites are located in deep oxygenated waters where preservation of organic matter was relatively poor. Although these deeper sites contribute little to an understanding of paleocirculation, their chemistry does provide insights into the processes of accumulation of organic matter in deep water, into the effects of early thermal diagenesis (catagenesis), and at one site (471), there is an example of hydrocarbon migration.

\section{SITES 467 AND 468}

These sites, at water depths of 2130 meters in the San Miguel Gap (467) and at 1800 meters on the Patton Escarpment (468), are located in the California Border- 
land. Their sediments contain a record of paleoenvironmental changes in the California Current.

\section{Source, Preservation, and Paleoenvironment}

The sediments at these two sites are generally rich in organic matter (Pisciotto, this volume; Gilbert and Summerhayes, this volume). Upper Miocene sediments at Site 467 contain up to $7.8 \%$ total organic carbon (TOC) (Gilbert and Summerhayes, this volume). At Site 468 the maximum TOC is $6.5 \%$, in middle Miocene sediments (Pisciotto, this volume).

The downhole profile of organic carbon at Site 467 can provide some clues about paleoenvironmental changes. Gilbert and Summerhayes (this volume), and Summerhayes (in press) argue that changes in oceanic circulation towards the end of the middle Miocene led to an increase in upwelling, heightened productivity in surface waters, and enhanced oxygen depletion within the oxygen minimum zone. As a result, more organic matter was supplied to the bottom, and the low oxygen levels favored the preservation of this material. The abundance of organic matter at this site, together with the absence of an exponential downhole decrease in TOC, imply that bottom waters were consistently oxygen poor. That these bottom waters were not necessarily anoxic is suggested by the sedimentological data. For instance, in Section 467-60-1, zones of laminated sediment that were probably deposited under anoxic bottom waters alternate with zones of bioturbated sediment (see Site 467 report, this volume). At nearby Site 468 the local zone of TOC enrichment near the top of the middle Miocene section (Pisciotto, this volume) probably represents a temporary period of extreme oxygen depletion; the cores are disturbed by drilling, so we do not know if these sediments were laminated at time of deposition.

Several lines of evidence suggest that anoxic conditions were more strongly developed at Site 467 than at 468. For example, Simoneit and Mazurek (this volume) find free sulfur in their Site 467 samples, as well as pristane/phytane ratios of about 1.0. Furthermore, there are intact carotenoid pigments, and large amounts of tetrapyrrole pigments in the shallow samples at this site (Louda and Baker, this volume). High levels of methane and sulfur-containing gases also indicate reducing conditions (Whelan and Hunt, this volume; Gilbert and Summerhayes, this volume). Perylene, which is commonly found in anoxic sediments (Hites et al., 1980), is present at all depths at Site 467 (Simoneit and Mazurek, this volume; Rullkötter et al., this volume; Louda and Baker, this volume). In contrast, pristane/phytane ratios are greater than 1.0 at Site 468 (Simoneit and Mazurek, this volume), and methane concentrations are rather low (Whelan and Hunt, this volume), suggesting a more oxidizing depositional environment. The somewhat lower TOCs at Site 468 are consistent with this interpretation (Pisciotto, this volume; Gilbert and Summerhayes, this volume). Site 468 is further offshore than is 467 , and may have been located under a less well developed part of the California Current upwelling system. This would have meant a lower supply of organic matter and a weaker oxygen minimum zone at Site 468 -hence less accumulation of organic matter.

One problem with using the pristane/phytane ratio, perylene abundance, and the presence of sulfur or sulfur compounds as indicators of anoxia is that they may apply more to what occurs immediately beneath the sediment/water interface than to the conditions that exist in near-bottom water. If this is the case, then we can understand how it is possible to have bioturbated sediments (hence oxic bottom water) that have the chemical indications of anoxia.

Most of the organic matter deposited at these two sites is of marine origin. Marked changes in organic facies downhole at Site 467 result from changes in the supply of organic matter with time. Deeper than Core 20 the organic matter is classified as Type II (marine) according to pyrolysis data (Rullkötter et al., this volume) and is mostly amorphous with substantial subordinate structured marine organic matter (Gilbert and Summerhayes, this volume). The one exception to this generalization is in Core 63, where Gilbert and Summerhayes analyzed a high TOC $(7.8 \%)$ sample full of amorphous and structured marine material, whereas Rullkötter et al. analyzed a low TOC $(1.5 \%)$ deeper sample that had Type III (terrestrial) kerogen and contained abundant terrestrial plant fragments. This sample may have been a thin turbidite; clearly it is not representative of the deep section here. Above Core 20 there is a substantial minor terrestrial component-averaging $20 \%$ of the kerogen fraction, according to the data of Gilbert and Summerhayes (this volume). Pyrolysis shows that these sediments are mixtures of Types II (marine), and III (terrestrial) (Rullkötter et al., this volume). Summerhayes (in press) used these data to conclude that prograding clastic sedimentation has been burying and diluting marine organic matter here since the late Miocene.

More detailed geochemical analyses support these observations about the physical characteristics of the organic matter. For instance, the $\delta^{13} \mathrm{C}$ values of kerogen at these sites range between $-20 \%$ and $-23 \%_{0}$, typical of marine planktonic remains (Simoneit and Mazurek, this volume). The distributions of various lipid components also indicate that most of the organic matter is marine. The aliphatic hydrocarbons have a strong microbial signature in the "hump" of unresolved components between $C_{16}$ and $C_{20}$, whereas the abundant $C_{17}$ and $\mathrm{C}_{19}$ alkanes represent algal remains (Simoneit and Mazurek, this volume; McEvoy et al., this volume; Rullkötter et al., this volume). Sterols and long chain ketones typical of marine-sourced organic matter are abundant at Site 467 (McEvoy et al., this volume). And sediments from Site 468 also contain predominantly marine-type $n$-alkanes (Simoneit and Mazurek, this volume).

Terrestrially derived lipid compounds are also present, suggesting that the lipid fraction is a mixture of marine and terrigenous components. Long chain $n$-alkanes and $n$-alkanoic acids from land plant waxes are present in all samples and dominate the alkane fractions 
of some samples (Simoneit and Mazurek, this volume; McEvoy et al., this volume; Rullkötter et al., this volume). In addition, Simoneit and Mazurek (this volume) found dehydroabietic acid in their samples. This compound is presumed to be derived from resinous plants. Finally, Louda and Baker (this volume) find small amounts of dealkylated $\mathrm{Cu}$ or $\mathrm{Ni}$ etioporphyrins in the tetrapyrrole pigments of these sediments. These particular porphyrins are terrigenous source indicators (Palmer and Baker, 1978).

The overall picture that emerges from these various data is that the major organic input comes from marine phytoplankton, with supplemental input from land plants. The organic matter has been modified substantially by microbial activity. Perylene is common in these continental margin sediments. Various investigators have interpreted this compound as a terrigenous marker. But Louda and Baker (this volume) find no correlation between perylene and land-derived porphyrins. They do find a probably thermally controlled increase in alkylsubstituted perylenes at Site 467 . This suggests that perylene may not be a valid marker for terrigenous input. Evidence suggests that perylene is abundant where depositional conditions were reducing, and that perylenes may be produced during early catagenesis.

Some of the organic matter in these sediments is recycled. At Site 467 , samples contain a $\mathrm{C}_{28}$ triterpenoid compound that appears to be derived from the Monterey Shale (McEvoy et al., this volume; Simoneit and Mazurek, this volume; Rullkötter et al., this volume).

\section{Thermally Controlled Diagenesis}

The alteration of phorbides and chlorins to porphyrins is recognized at Site 467 and seems to be thermally controlled. McEvoy et al. (this volume) detect chlorins in shallow sediments, but only find Ni-porphyrins in deeper sediments. Louda and Baker (this volume) find a progressive downhole sequence of aromatization of phorbides and chlorins; nickel chelation; formation of alkylated porphyrins; and, finally, the appearance of vanadyl porphyrins, with increasing maturation.

Light hydrocarbons also show a steady increase downhole at Site 467, apparently in direct response to thermal maturation (Fig. 1), as suggested by Whelan and Hunt (this volume) and by the gas data of Gilbert and Summerhayes (this volume). Because the abundance of hydrocarbons tend to follow TOC, it seems most unlikely that these components have migrated into the section. Two samples (from Sections 467-74-1, and 467-85-4) had negligible amounts of hydrocarbons. One (74-1) is described in the Initial Core Descriptions as porcellanite, the other $(85-4)$ is described as volcanic ash. Both are lithologically dissimilar from the remainder of the analyzed samples (mudstones) and were not used in our plot (Fig. 1). Most of the light hydrocarbons correlate with one another, indicating a common origin (Whelan and Hunt, this volume). The exceptions are aromatic and gem-dimethyl hydrocarbons, which probably come from different sources than the bulk of the hydrocarbons analyzed (Whelan and Hunt, this volume).

The vitrinite reflectance increases steadily downhole, indicating gradually increasing levels of maturation (Rullkötter et al., this volume). Although the vitrinite values stay below 0.5 , the beginning of hydrocarbon generation is indicated by an increase in the ratio of extractable bitumens to TOC at 800 to 900 meters (Rullkötter et al., this volume).

At Site 468 , although there are only very small concentrations of hydrocarbons (Whelan and Hunt, this volume), there is a systematic downhole increase in the ratio of $\mathrm{C}_{2}+\mathrm{C}_{3}$ gases to TOC (Fig. 2). This systematic trend is not evident for the $\mathrm{C}_{4}-\mathrm{C}_{7}$ or the $\mathrm{C}_{8}$ hydrocarbons. Nevertheless, the highest ratios of $\mathrm{C}_{4}-\mathrm{C}_{7} / \mathrm{TOC}$ and $\mathrm{C}_{8}$ /TOC are found at the bottom of the hole (see the data in Whelan and Hunt, this volume). These weak trends may reflect very early catagenesis.

\section{SITES 469, 470, 471, AND 473}

These sites are located deep on the continental margin, at water depths of 3790 meters, 3750 meters, 3116 meters, and 3267 meters, respectively. Although they were chosen for biostratigraphic studies of changes in circulation, such changes do not appear to be reflected in the organic geochemistry. The organic geochemical data can be used to characterize deep ocean sedimentation in this region, and to further document early thermal diagenesis as well as hydrocarbon migration.

\section{Source, Preservation, and Paleoenvironment}

The sediments at these sites have average TOCs below $1.0 \%$ (Gilbert and Summerhayes, this volume). TOC generally decreases with increasing burial depth, although there is considerable variation at Sites 471 and 473 obscuring this tendency (Pisciotto, this volume). These relatively low TOCs reflect not only a seaward decrease in productivity compared with the borderland, but also deposition at slow rates and under strongly oxygenated bottom waters.

At Site 469 , the kerogen data suggest a mixed marine-terrestrial source for the organic matter, with one sample having up to $35 \%$ recognizable terrestrial organic remains (Gilbert and Summerhayes, this volume). Lipid marker compounds confirm the marine-terrestrial mixture, and carbon isotopes suggest that marine material is predominant $\left(\delta^{13} \mathrm{C}=-22 \%\right.$ ) (Simoneit and Mazurek, this volume). Pristane/phytane ratios greater than 1.0 suggest that these materials were deposited under oxidizing conditions (Simoneit and Mazurek, this volume).

The two kerogen analyses from Site 470 suggest predominantly terrestrial organic matter in the upper Miocene, rocks and sediments following a much lower terrestrial input in the middle Miocene rocks and sediments (Gilbert and Summerhayes, this volume).

On the basis of kerogen analysis, Rock-Eval pyrolysis, and $n$-alkane distributions, Rullkötter et al. (this volume) conclude that the organic matter at Site 471 is 


\section{SITE 467}
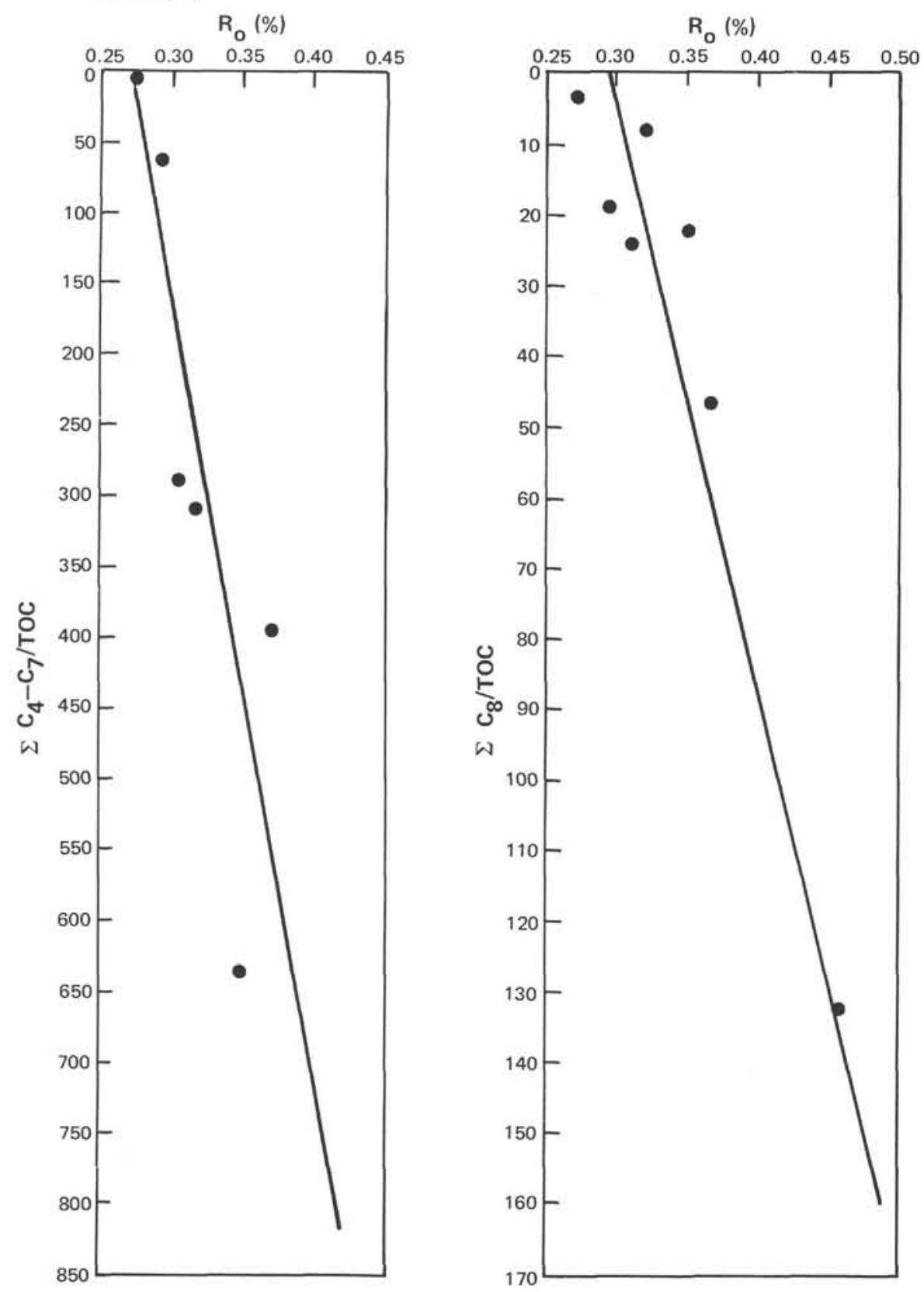

Figure 1. Dependence of light hydrocarbon concentrations upon degree of thermal maturation in Neogene sediments from DSDP Site 467, California Borderland. (Vitrinite reflectance data $\left(R_{o}\right)$ are interpolated from Rullkötter et al. [this volume]. Hydrocarbon data are from Whelan and Hunt [this volume]; hydrocarbon/TOC ratios remove fluctuations caused by the varying abundance of organic matter downhole.)

mostly terrestrially derived. One of their samples (Core 13, Section 7) has a much more marine character than the others. Gilbert and Summerhayes (this volume) find a substantial marine algal component in that same core. Although there is a subordinate marine component in the kerogens in the shallow parts of the section, this is absent from the deeper part of the section, where the subordinate components are all terrestrial; the major component is amorphous (Gilbert and Summerhayes, this volume). The sedimentological evidence shows that the deeper section belongs to a submarine fan complex, whereas the younger sediments are more pelagic. The organic facies data tend to support this picture. Much of the amorphous kerogen from the deep section may have had terrestrial precursors.

Because pristane/phytane ratios are less than 1.0, and because these sediments contain perylene and alkyl thiophenes, depositional conditions were probably reducing (Rullkötter et al., this volume). Given the substantial water depth $(3116 \mathrm{~m})$, and open ocean set- 
SITE 468

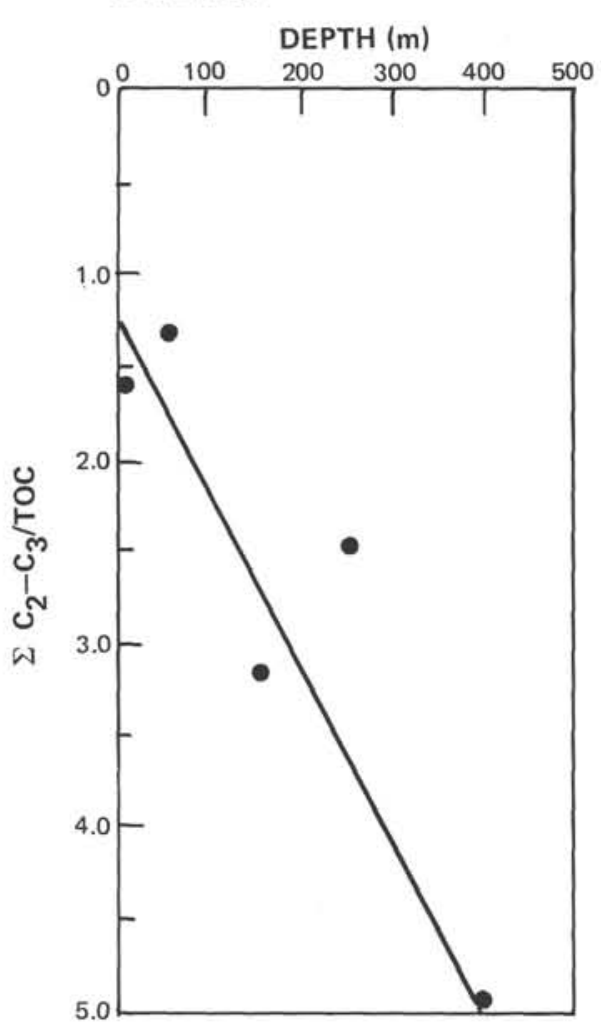

SITE 469

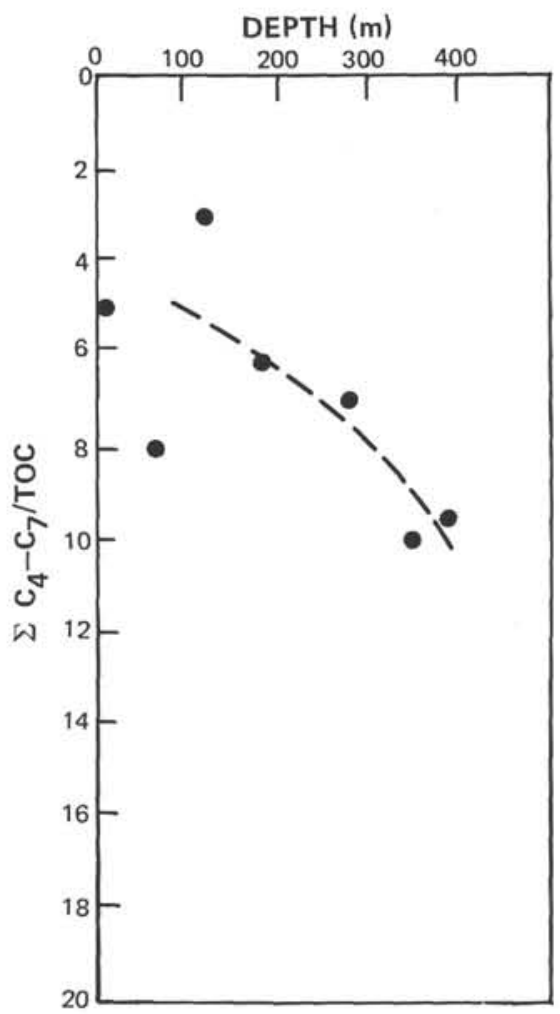

SITE 469

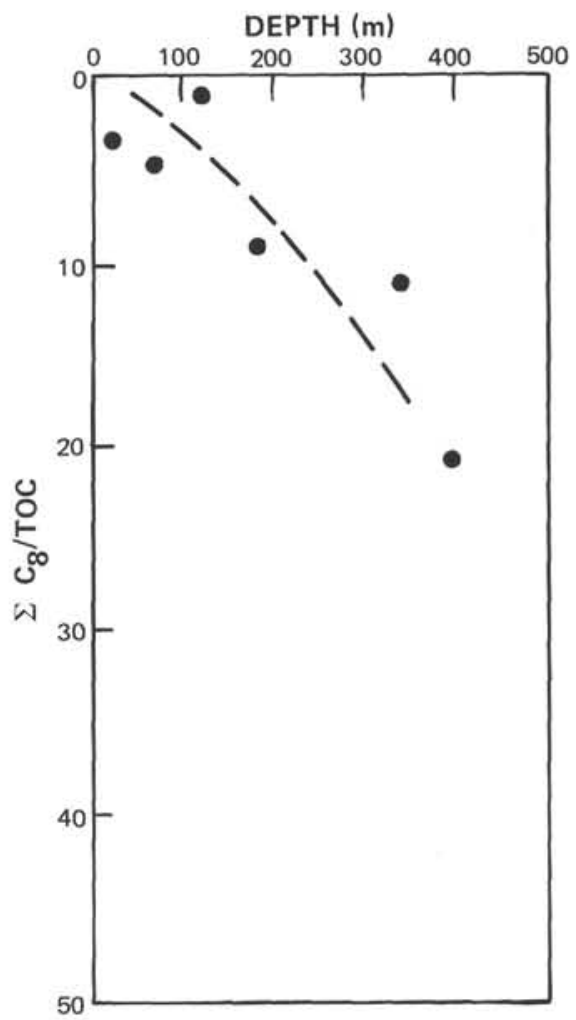

Figure 2. Probable dependence of light hydrocarbon concentrations upon degree of catagenesis in Neogene sediments from DSDP Sites 468 and 469, offshore California. (Hydrocarbon data are from Whelan and Hunt [this volume].)

ting, however, it seems unlikely that bottom waters were anoxic here. Presumably the anoxic conditions prevailed close beneath the sediment/water interface.

At Site 473 the few analyses that were made suggest that there is a highly variable supply of organic matter. This is probably because the section is full of turbidites (see Gilbert and Summerhayes, this volume; and the Site 473 report).

\section{Thermally Controlled Diagenesis}

As noted at some of the other sites, at Site 469 there is a downhole increase in the ratios of light hydrocarbons to TOC (Fig. 2). The presence of only small quantities of light hydrocarbons at this site and the lack of correlation between them indicate a low degree of thermal stress (Whelan and Hunt, this volume). Nevertheless, the trend shown in Figure 2 suggests that thermal stress is making itself felt and has caused some diagenetic changes. These data do not seem to show the effects of intrusion of a sill at 365 to 387 meters sub-bottom depth. Yet kerogens from this site apparently show slight changes that may have been caused by this intrusion (Simoneit and Mazurek, this volume).

The data set from Site 471 is more comprehensive, and vitrinite reflectance studies clearly indicate substantial maturation towards the oil window (Rullkötter et al., this volume). As vitrinite reflectance increases, there are decreases in the abundance of long chain $n$-alkanes, in the Carbon Preference Index, and in the pristane/ phytane ratio, and increases in the abundances of cyclic and alkylated aromatic hydrocarbons (Rullkötter et al., this volume). The Ni-porphyrins that are found in the deeper sediments at this site may also have been generated thermally (Louda and Baker, this volume). Thermal alteration indices also increase near the bottom of the hole, confirming an increase in the degree of maturation (Gilbert and Summerhayes, this volume).

The most striking feature of the hydrocarbon distribution is the anomalously large concentration of light hydrocarbons at depths greater than 500 meters at Site 471. Whelan and Hunt (this volume) report $28,600 \mathrm{ng}$ hydrocarbon $\left(\mathrm{C}_{2}-\mathrm{C}_{8}\right)$ per $\mathrm{g}$ sediment at a sub-bottom depth of 650 meters. Migration from a deep, hot source, probably near the diabase sill at 823 meters, is invoked to explain these high values. In situ generation of hydrocarbons seems highly unlikely in view of the low maturation measured at these depths (Rullkötter et al., this volume). The deep sediments above the sill are baked and hydrothermally altered metalliferous sediments, indicating intense local heating. The effects of the heat event were confined to the immediate vicinity of the sill, though the products of that heating appear to have migrated away from its vicinity into the overlying section.

\section{CONCLUSIONS}

1. Organic matter is predominantly marine in character. There is a substantial terrestrial contribution in the upper part of the section at Site 467 and in the deeper part of the section at Site 471 . 
2. Pelagic sedimentation accounts for deposition of the marine organic matter; the terrestrial components were probably transported by turbidity currents at Site 471. Slow moving turbidity flows may have transported terrestrial organic matter to Site 467 , where there is little evidence of turbidity currents.

3. TOC is highest in areas of high productivity, low oxygen concentration, and fairly rapid burial. TOCs are low where upwelling is less, where oxygenation is better developed, and where sedimentation rates are rather slow.

4. Three sites show some evidence of paleoenvironmental changes. Site 467 shows a change from low TOC in the middle Miocene, through high TOC in the late Miocene to Pliocene, to moderate TOC in the late Pliocene to Quaternary. This reflects changes in upwelling, productivity, and oxygen depletion of bottom waters through time. A change from a marine organic facies to mixed marine-terrestrial in the late Pliocene reflects an increase in the supply of terrigenous materials with time. At Site 468 a middle Miocene TOC maximum probably records some upwelling event or a downward excursion of the oxygen minimum. At Site 471 the change from more terrestrial material deep in the section to more marine material shallow in the sec- tion reflects the change from a deep sea fan complex to more pelagic deposition.

5. All of the sections examined are immature (i.e., have not reached the point of oil generation). But Sites $467,468,469$, and 471 show the effects of thermal stress. Organic matter is being altered by thermal diagenesis at these sites, with the production of light hydrocarbons in small quantities.

6. Migrated $\mathrm{C}_{2}-\mathrm{C}_{8}$ hydrocarbons occur deep in the section at Site 471 , possibly in association with hydrothermally altered sediments above a diabase sill.

\section{ACKNOWLEDGMENTS}

Colin Summerhayes thanks Exxon Production Research Company for permission to publish this paper. B. Haq and R. Yeats reviewed the manuscript.

\section{REFERENCES}

Hites, R. A., LaFlamme, R. E., Windsor, J. G., et al., 1980. Polycyclic aromatic hydrocarbons in an anoxic sediment core from the Pettaquamscutt River (Rhode Island, U.S.A.). Geochim. Cosmochim. Acta, 44:873-878.

Palmer, S. E., and Baker, E. W., 1978. Copper porphyrins in deep sea sediments: a possible indicator of oxidized terrestrial organic matter. Science, 201:49-51.

Summerhayes, C. P., in press. Oceanographic controls on organic matter in the Miocene Monterey Formation, offshore California. AAPG-SEPM Spec. Publ. 